\title{
Northward Range Expansion of Subarctic Upper Trophic Level Animals into the Pacific Arctic Region
}

By Kathleen M. Stafford, Edward V. Farley, Megan Ferguson,

Kathy J. Kuletz, and Robert Levine
ABSTRACT. Studies of the impacts of climate change on Arctic marine ecosystems have largely centered on endemic species and ecosystems, and the people who rely on them. Fewer studies have focused on the northward expansion of upper trophic level (UTL) subarctic species. We provide an overview of changes in the temporal and spatial distributions of subarctic fish, birds, and cetaceans, with a focus on the Pacific Arctic Region. Increasing water temperatures throughout the Arctic have increased "thermal habitat" for subarctic fish species, resulting in northward shifts of species including walleye pollock and pink salmon. Ecosystem changes are altering the community composition and species richness of seabirds in the Arctic, as water temperatures change the available prey field, which dictates the presence of planktivorous versus piscivorous seabird species. Finally, subarctic whales, among them killer and humpback whales, are arriving earlier, staying later, and moving consistently farther north, as evidenced by aerial survey and acoustic detections. Increasing ice-free habitat and changes in water mass distributions in the Arctic are altering the underlying prey structure, drawing UTL species northward by increasing their spatial and temporal habitat. A large-scale shuffling of subarctic and Arctic communities is reorganizing high-latitude marine ecosystems.

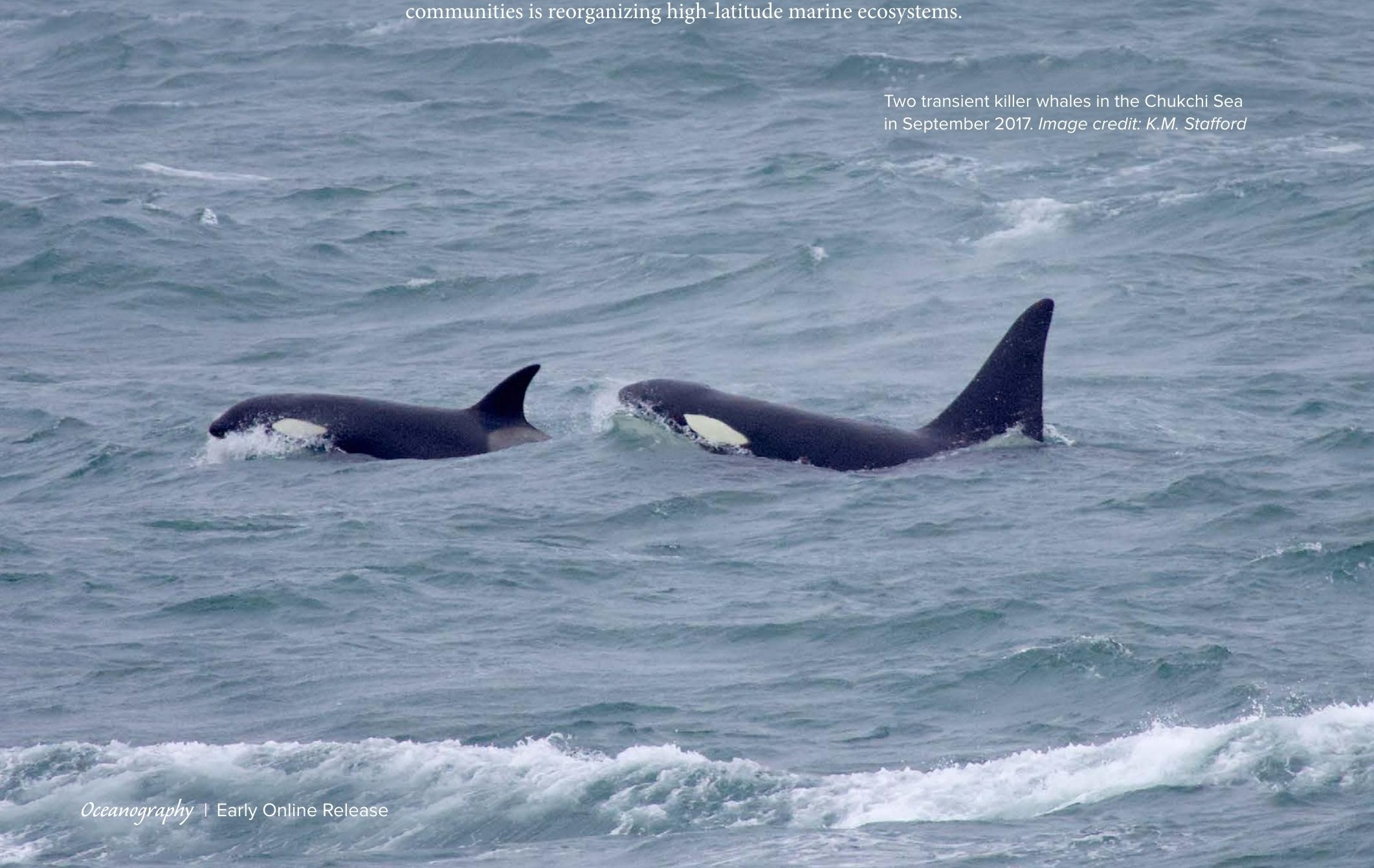




\section{INTRODUCTION}

Poleward range expansion of plant and animal species is one clear indication of climate change. Such distribution shifts in the ocean may be driven by changes in temperature, nutrients or, as in the Arctic and Antarctic, sea ice extent. These atmospherically driven alterations are inextricably linked to changes in wind-driven mixing or circulation, which affects nutrient supply; greenhouse gases, which trap heat; and subsurface and deep ocean heat, which drives sea ice declines (TamarinBrodsky and Kaspi, 2017; Woodgate and Peralta-Ferriz, 2021). Under new climate regimes, species whose life history strategies allow them to rapidly adapt or expand into novel habitat, such as large, migratory generalist feeders, can become climate change "winners" (Kortsch et al., 2015; Moore and Reeves, 2018). Subsequent impacts on endemic ecosystems will depend on resource availability and competition among species. As the climate continues to warm, temperate regions are becoming "tropicalized" and Arctic regions are becoming "borealized," with subarctic species increasing in abundance and expanding their ranges northward (Fossheim et al., 2015; Alabia et al., 2018; Polyakov et al., 2020).

While climate change is altering the entire Arctic, not every region in the highly heterogeneous Arctic is equally affected (e.g., Moore et al., 2019; Polyakov et al., 2020; Mueter et al., 2021a). In the Atlantic, there are two wide, deep, high-latitude gateways to the Arctic: Davis Strait (300-900 km wide) and Fram Strait/Barents Sea ( $\sim 50 \mathrm{~km}$ wide). The sole gateway to the Pacific Arctic is through the narrow Bering Strait $(80 \mathrm{~km})$, south of the broad, shallow Chukchi Sea shelf (Figure 1). Observed differences between the Atlantic and Pacific Arctic regions include a much greater increase in the open water season in the Barents Sea than in the Chukchi Sea, and differences in water mass composition and advection of heat and nutrients, all of which shape ecosystem structure (Hunt et al., 2013; Oziel et al., 2017).
Numerous recent studies illustrate how changes in sea ice are potentially altering biological components of subarctic and Arctic marine ecosystems. Many of these studies focus on the impacts of climate change on Arctic endemic species (Laidre et al., 2008; Divoky et al., 2021), ecosystems (Post et al., 2013; Grebmeier and Maslowski, 2014; Pecuchet et al., 2020 ), and the people who rely on them (Huntington et al., 2016, 2020, 2021). In particular, the inclusion of upper trophic level (UTL) taxa in the suite of measurements collected by the Distributed Biological Observatory provides novel information on ecosystem dynamics at key locations across decadal time scales (Moore and Kuletz, 2019; Stafford et al., 2021). Several recent studies also highlight the role that UTL consumers such as marine fish, birds, and mammals can play as bellwethers of climate change, and how understanding their abundances, distributions, and diets can aid in tracking ecosystem-level biological responses to rapid change (e.g., Moore et al., 2014, 2019; Sydeman et al., 2021).

Here, we review recent information on northward range expansions of sub- arctic marine fish, seabirds, and mammals whose life histories have in some instances included limited seasonal occupation of the Arctic, with a focus on exemplar case studies from the Pacific Arctic Region. Our overarching goal here is to provide an updated overview of observed recent changes in the spatial and temporal distributions of subarctic marine fishes, seabirds, and marine mammals, and to explain related linkages among changes in biology, the atmosphere, the ocean, and the cryosphere.

\section{MARINE FISHES}

Marine fish species can rapidly track environmental change (Sorte et al., 2010; Pinsky et al., 2013). This is evident in the borealization of the Barents Sea in particular, where subarctic species including mackerel and Atlantic cod are expanding their ranges from the North Atlantic (Johannesen et al., 2012) while the distribution of Arctic species is retracting northward (Fossheim et al., 2015; Frainer et al., 2017). As the region continues to warm, the thermal habitat for boreal species has shifted farther into the Arctic (Eriksen et al., 2020), and

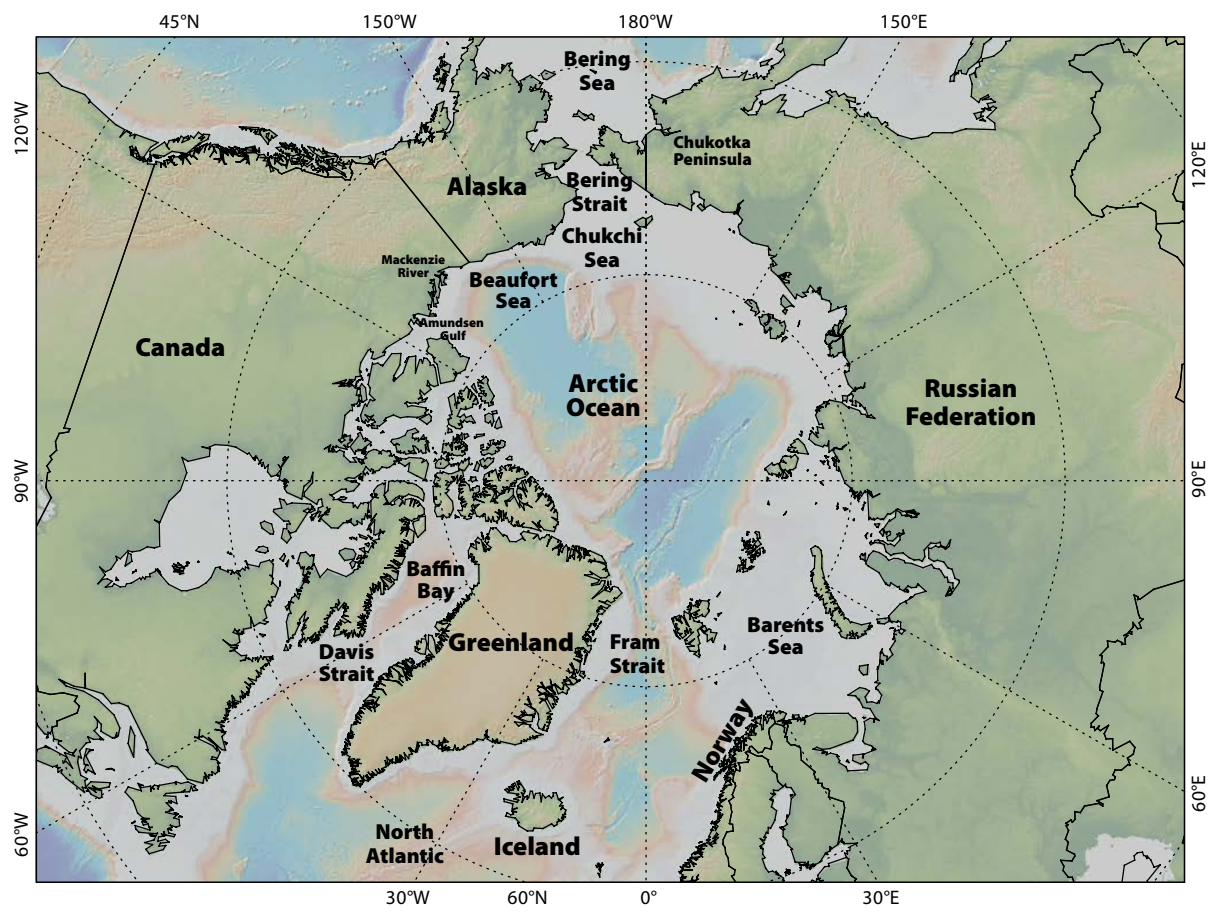

FIGURE 1. Map of the Arctic showing major gateways and waterways. Map made with GeoMapApp (http://www.geomapapp.org/; Ryan et al., 2009). 
generalist boreal fishes are likely to outcompete the specialist diets of Arctic species (Kortsch et al., 2015).

Sigler et al. (2011) examined fish distribution records for the Pacific Arctic Region from the first decade of this century and found clear divisions in the distributions of planktivorous versus piscivorous species between the Bering Sea and the Chukchi and Beaufort Seas, as well as regional differences in taxa among bottom and surface fishes. Despite some evidence of northward migrations of subarctic species from the Bering Sea, these authors concluded that the persistence of the Bering Sea cold pool (Stabeno et al., 2001) would restrict range extensions of bottom fish such as walleye pollock, while pelagic species, such as pink salmon, might not be restricted by this thermal barrier (Sigler et al., 2011). However, given the retraction and possible collapse of the cold pool in recent years (Stabeno and Bell, 2019), more recent data suggest that these range extensions are long term (Grüss et al., 2021).

\section{Walleye Pollock}

Walleye pollock are widely distributed throughout the North Pacific, with known spawning grounds across the continental shelves from Japan to western Canada (Bailey et al., 1999). Cold bottom water in winter typically restricts the northward extent of the population. Adult pollock seasonally migrate northward and inshore in summer and then return to the outer shelf to avoid the cold pool (Kotwicki et al., 2005). A reduction in the size of the cold pool lessens the barrier for adult pollock to remain on the inner and northern shelf throughout the year, resulting in a northward shift during recent warm conditions (Stevenson and Lauth, 2019; Eisner et al., 2020; Grüss et al., 2021).

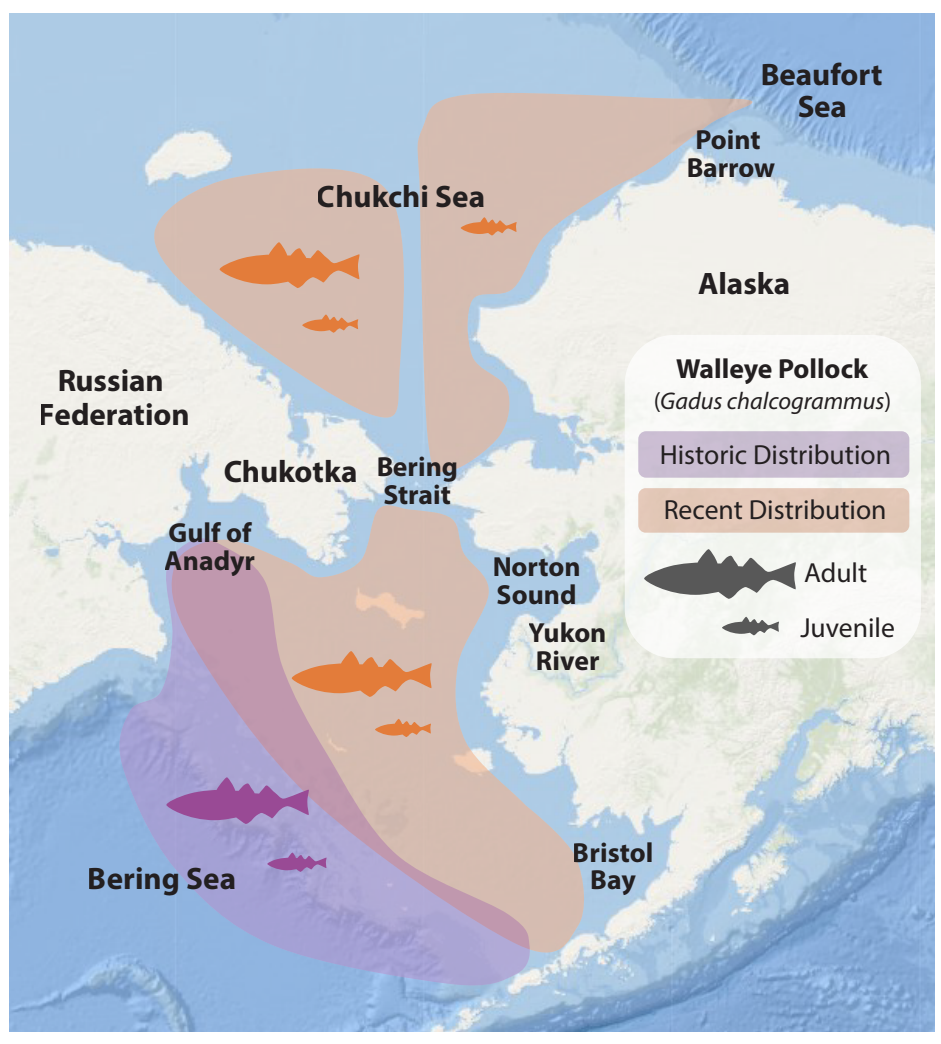

FIGURE 2. Historic and recent observations of walleye pollock distributions in the Bering and Chukchi Seas. Recent warming has led to a northward shift of the population in the Bering Sea (approximate distributions from Eisner et al., 2020), and surveys have reported large pollock populations in the eastern (juvenile only; recent work of author Levine) and western (adult and juvenile; Orlov et al., 2020) Chukchi Sea.
North of the Bering Strait, the summer forage fish community is dominated by small juvenile Arctic cod (De Robertis et al., 2017). Other common forage fishes in the region include capelin and Pacific herring, both of which are observed nearshore and largely in the southern Chukchi Sea. Juvenile pollock had previously been found in very low densities with few adults present (Wyllie-Echeverria, 1995; Mecklenburg et al., 2007; Rand and Logerwell, 2011; Goddard et al., 2014). Surveys during the recent period of extreme warming (2017-2020) indicate that while the distributions of the other pelagic forage fishes have not significantly changed, pollock abundance in the Pacific Arctic has substantially increased (Figure 2). In the eastern Chukchi Sea, juvenile pollock were widespread and highly abundant in 2017 and 2019 and found in comparable densities to Arctic species (Levine et al., 2021; recent work of author Levine). In the Russian sector, surveys in 2018 and 2019 found a significant increase in both juvenile and adult pollock north of the Chukotka Peninsula (Orlov et al., 2020). It is hypothesized that the recent increase in adult pollock in the northern Bering Sea serves as a source population for the larval and juvenile population observed in the Chukchi and Beaufort Seas (Levine et al., 2021) due to increased transport of Pacific water (Woodgate and Peralta-Ferriz, 2021) that advects juvenile fish northward.

Juvenile pollock growth rates exceed those of other gadid species under the warm conditions of the Arctic summer (Laurel et al., 2016), potentially allowing them to outcompete Arctic species; however, their hatch and survival rates are reduced under the seasonal freezing conditions (Laurel et al., 2018).

Thus, while the substantial increase in juvenile pollock in the Pacific Arctic suggests that environmental conditions now allow pollock to extend into the Chukchi Sea on a seasonal basis, their ability to establish permanent populations in the Arctic remains unknown. 


\section{Pink Salmon}

Among salmonids, pink salmon are the most abundant species in the North Pacific Ocean (Ruggerone and Irvine, 2018) and have the broadest distribution in the Pacific Arctic Region. They occur from the large Yukon River to smaller coastal streams as far north as Point Barrow (Craig and Haldorson, 1986). Vagrants have also been found upstream in the Mackenzie River, extending eastward across the Beaufort Sea toward Amundsen Gulf, and along the east coast of Greenland (Dunmall et al., 2013, 2018). Spawning pink salmon have also been documented along the Chukotka Peninsula coastline from the northern Bering Sea into the Chukchi Sea and as far west as the Kolyma River (Radchenko et al., 2018). While pink salmon abundance in northern regions of their range is still quite low in relation to stocks farther south, there is evidence that the abundance of some northern stocks is increasing. For example, adult pink salmon have become more prevalent in subsistence catches in the high Arctic, particularly during evennumbered years (Dumnall et al., 2013, 2018). Furthermore, a survey during late summer 2007 found large numbers of juvenile pink salmon in the southern Chukchi Sea; these juveniles were larger and had higher energy content than juvenile pink salmon captured farther south (Moss et al., 2009). Consequently, adult pink salmon returns to the Beaufort Sea coast during 2008 were higher than in 2007 (Dunmall et al., 2013, 2018). It is still not clear whether the large catch of juvenile pink salmon in the Chukchi Sea in 2007 contributed to the higher returns in 2008. Conditions in both freshwater and marine environments are important to the survival of pink salmon (Farley et al., 2020). In the northern extent of pink salmon distribution, cold river and stream temperatures in the freshwater environment are believed to limit salmon production (Dunmall et al., 2016); however, continued warming of air and stream temperatures, and longer periods of ice-free conditions, may benefit salmon survival in this environment (Nielsen et al., 2013).

\section{SEABIRDS}

Seabirds link Arctic and subarctic marine and terrestrial ecosystems because they require land to nest and raise young, but forage in the ocean. Globally, pelagic seabird occurrences and distributions reflect the presence of the surface and subsurface zooplankton and forage fish upon which they feed (e.g., Sydeman et al., 2010). In the Pacific Arctic region, seabirds have been associated with underwater features and water mass characteristics that aggregate their prey (Gall et al., 2013; Kuletz et al., 2015). During chick rearing, seabirds must find sufficient highquality prey within foraging distance of their nests, a distance that can vary from a dozen to hundreds of kilometers, depending on species and reproductive phase. When not breeding, many species are capable of long-distance migrations covering thousands of kilometers.

Sea ice cover in the Arctic affects seabird foraging, and extensive ice can restrict their access to prey. However, the marginal ice zone can provide a rich foraging opportunity (Hunt et al., 1996), as zooplankton and fish species often aggregate at ice edge habitats (Daase et al., 2021). Changes in sea ice extent and water temperature have resulted in changes in the available prey field for seabirds throughout the Arctic (Mallory et al., 2010; Frederiksen et al., 2013; Gall et al., 2017; Mueter et al., 2021a). For instance, in the North Atlantic, little auk wintering distribution expands and contracts with the distribution of their subarctic copepod prey, which is shifting northward (Amélineau et al., 2018). In the Pacific Arctic, low amounts of sea ice and warmer sea temperatures have been associated with low reproductive success and seabird die-offs, apparently due to low prey availability (Duffy-Anderson et al., 2019; Romano et al., 2020).

The timing of spring ice retreat in the Pacific Arctic has been shown to affect seabird distribution on the Bering Sea shelf, with contrasting patterns between birds that forage at the water's surface and species that are subsurface foragers (Hunt et al., 2018). Early spring sea ice retreat thus affects the spatial distributions of seabird species evident in summer and alters seabird communities. Ecosystem changes are clearly altering the community composition and species richness of seabirds in the Arctic (Descamps and Strøm, 2021; Mueter et al., 2021b).

Four decades of at-sea surveys (available in the North Pacific Pelagic Seabird Database; Drew and Piatt, 2015) generally show that decreased sea ice cover and higher ocean temperatures during the first decade of this century favored planktivorous seabirds over piscivorous seabirds in the Chukchi Sea (Gall et al., 2017). With further warming, some species have shifted their overall distributions northward, likely in search of food (Kuletz et al., 2020).Will et al. (2020) concluded that conditions during the relatively warm years of 2016-2019 were detrimental to planktivorous auklets nesting in the northern Bering Sea. Because warmer ocean temperatures have been linked to the replacement of larger, lipidrich zooplankton species with smaller, lipid-poor species (Eisner et al., 2013), ongoing changes in the Pacific Arctic may no longer favor planktivorous seabirds.

In the Bering Sea, subarctic seabirds that appear to be expanding their post-breeding dispersal ranges northward include three species of Pacific albatrosses (Kuletz et al., 2014), northern fulmars (Renner et al., 2013), and ancient murrelets (Day et al., 2013). For all seabirds combined, there was a shift in distribution farther into the Pacific Arctic during the warm years of 20172019 compared to the previous decade (Figure 3). This northward shift included birds that breed in the Bering and Chukchi Seas (e.g., thick-billed murre), migrants that breed in the Southern Hemisphere but move to Alaska during their non-breeding season (e.g., shorttailed shearwater; Kuletz et al., 2020), 
and Atlantic species that might have crossed the Canadian Arctic Archipelago (e.g., northern gannet; Day et al., 2013). Based on data from the eastern Chukchi Sea, seabirds that had been spatially correlated with prey communities during a relatively cool year (2015) were decoupled from the same communities in a warm year (2017), suggesting that these seabird communities did not adapt, at least in the short term, to a rapid change in conditions (Mueter et al., 2021b).

\section{CETACEANS}

Marine mammals have exhibited phenological and distributional changes throughout the Arctic. Endemic Arctic marine mammals spend their lives in the Arctic, often closely associated with sea ice. A number of subarctic species, particularly cetaceans, have become regular summer and autumn visitors to the
Arctic, migrating into the region as sea ice melts in the spring or early summer and out of the region as the sea surface freezes in late autumn or early winter (Hamilton et al., 2021). As sea ice has declined in age, thickness, and extent throughout the Arctic, prey distributions have shifted and new migratory corridors have opened for subarctic marine mammal species (Buchholz et al., 2012; Berge et al., 2015; Storrie et al., 2018). These changes have expanded the temporal and spatial boundaries of habitat for cetaceans: they are now arriving in the Arctic earlier, staying later, and migrating farther north (Nieukirk et al., 2020; Ahonen et al., 2021).

\section{Killer Whales}

Killer whales are a globally distributed top predator with ecotypes that are distinguished by their phenotypes and

\section{Total Seabirds}

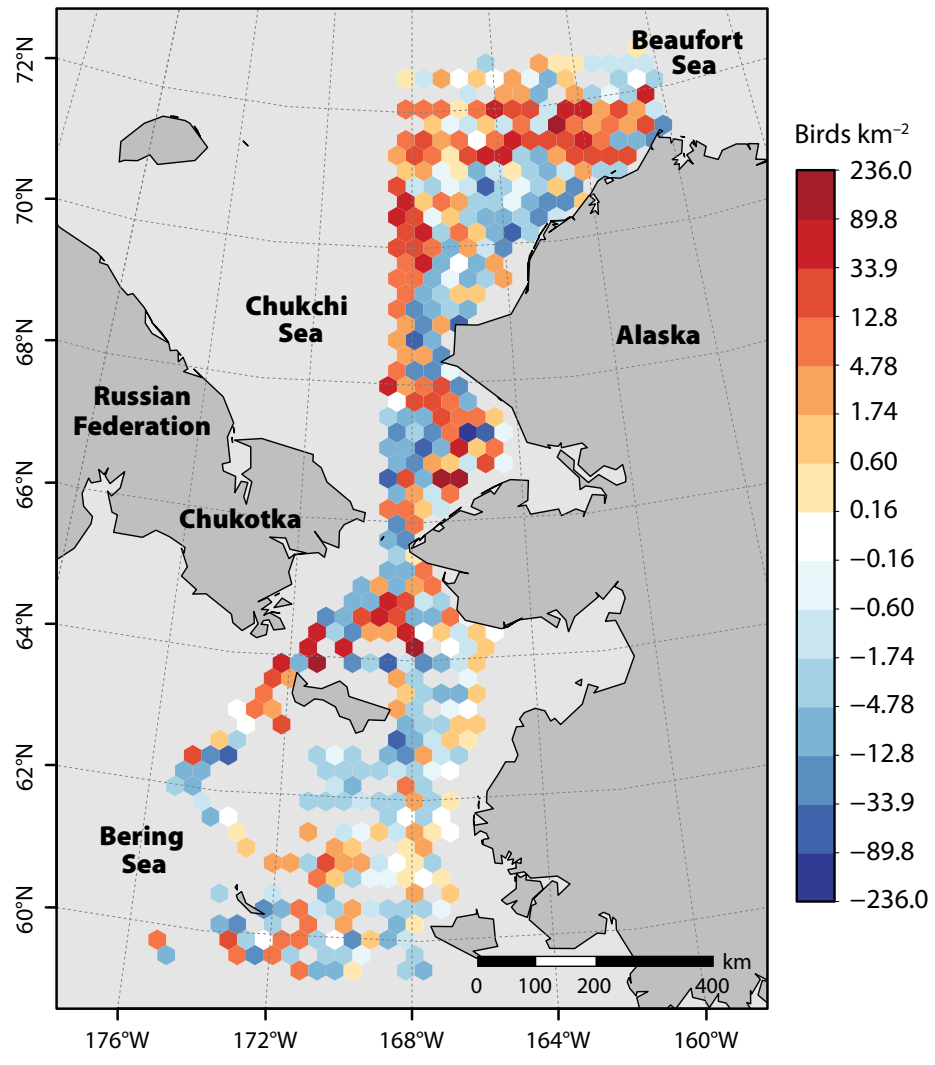

FIGURE 3. Distribution changes in the Pacific Arctic region for total seabird densities (birds $\mathrm{km}^{-2}$ ) during 2017-2019 compared to the previous decade. Cells with increasing (orange) and decreasing (blue) densities during 20172019 were based on mean densities of all observations within each $50 \mathrm{~km}$ grid cell. Adapted from Kuletz et al. (2020) preferred prey (de Bruyn et al., 2013). Killer whales are not a new species in the Arctic, as they have been documented there sporadically in summer months, feeding on a variety of marine mammal species (Stafford, 2019; LeFort et al., 2020). In the Arctic, killer whales avoid dense ice, and heavy multi-year sea ice once excluded them from most high Arctic regions during many months of the year. Though these whales still avoid heavy sea ice (Matthews et al., 2011), their increasing occurrence in the Arctic as sea ice declines in thickness and extent represents seasonal and geographic expansion. Recent (2010 to present) sighting and passive acoustic monitoring data provide evidence that this species is arriving in the Arctic earlier, departing later, and moving farther north in the eastern Canadian Arctic, and north and east in the Pacific Arctic (Higdon and Ferguson, 2009; S.H. Ferguson et al., 2010; Stafford, 2019; Figure 4). In the Pacific Arctic, passive acoustic monitoring has recently documented killer whales throughout the Chukchi Sea as far north as $75^{\circ} \mathrm{N}$ (recent work of author Stafford). This species has been heard in the Pacific Arctic as early as May and as late as October (Stafford, 2019). In both the Canadian and Pacific Arctic, the number of bowhead whales with killer whale scars has increased over time (Reinhart et al., 2013; George et al., 2017) as has evidence of depredation in bowhead whale carcasses (Willoughby et al., 2020). Matthews et al. (2019) posit that periodic ice entrapments of killer whales, which are usually fatal (Westdal et al., 2016), may slow their expansion into the Arctic, particularly as naive whales explore regions that can be ice choke points.

The northward range expansion, longer seasonal presence, and higher numbers of a top predator in the Arctic has the potential for top-down ecosystem reorganization and may represent the most immediate threat to Arctic endemic species (S.H. Ferguson et al., 2010). In the eastern Canadian Arctic, endemic narwhals, belugas, and bowhead whales 
change their behavior in the presence of killer whales (reviewed in Matthews et al., 2020). Lefort et al. (2020) suggest that this species could have a significant negative impact on narwhal populations in the Canadian Arctic Archipelago.

\section{Subarctic Baleen Whales}

The historical occurrence of humpback, fin, and minke whales north of Bering Strait was documented by Soviet scientists, particularly near the Chukotka Peninsula, from June to October (summarized in Clarke et al., 2013). These species are regularly found in the Bering Sea during summer (M.C. Ferguson et al., 2015), and fin whales are present there year-round (Stafford et al., 2010). Evidence from visual (shipboard and aerial) and acoustic monitoring suggest that their use of the Pacific Arctic may be increasing (Clarke et al., 2013, 2020; Brower et al., 2018).

Four decades of aerial surveys (Clarke et al., 2020) provide the most extensive information on subarctic whales in the US Pacific Arctic. Fin whales first appear north of Bering Strait in the aerial survey database in 2008, humpback whales in 2009, and minke whales in 2011. All three subarctic baleen whales were sighted in every month from July through October, although most of the sightings through 2019 occurred from July through September (Clarke et al., 2020). Furthermore, fin and humpback whale calves have been observed in the region (Clarke et al., 2020). Aerial survey observers have commonly recorded all three species in close proximity to one another and to gray whales, particularly in Hope Basin, a benthic hotspot in the south central Chukchi Sea (Clarke et al., 2020). In 2019, the number of subarctic baleen whales detected per kilometer surveyed over Herald Shoal, which is $\sim 145 \mathrm{~km}$ northwest of Point Lay, was 12.5 times greater than in any previous survey year. All three species have been documented feeding in the Pacific Arctic Region, and it is likely that the northward expansion of prey (krill and forage fish/ or small schooling fish) distributions provided the whales' motivation to migrate to the Pacific Arctic (Clarke et al., 2020).

\section{CONCLUDING THOUGHTS}

What does the future hold for upper trophic level species and communities in the Arctic? It is clear across taxa that the effects of climate change are variable and dependent on the different ecological requirements of communities, feeding guilds, species, and age classes. There is no indication that climate change in the Arctic is going to decelerate any time soon. The habitat changes that have been seen in the past two decades will become the "new normal" (Thoman et al., 2020). There is clear evidence of temporalspatial range expansion for many subarctic UTL species. Increasing ice-free habitat and changes in water mass distributions are altering the underlying prey structure and therefore attracting new UTL species, increasing habitat extent, and/or increasing the duration of residency in Arctic habitats. But for many subarctic species, annual sea ice cover, freezing temperatures, and months of darkness may still prevent them from becoming true Arctic residents. Pollock eggs and larvae are highly sensitive to cold temperatures, central place foraging seabirds need adequate nesting habitat within foraging distance of high prey abundance, and subarctic cetaceans can still be excluded from heavy ice as they risk injury to their dorsal fins and ice entrapment. To permanently expand northward, UTL species require the flexibility in physiology and behavior to adapt to ongoing habitat perturbations. If new species can adapt to yearround life in the Arctic, understanding the risks to Arctic endemic species from

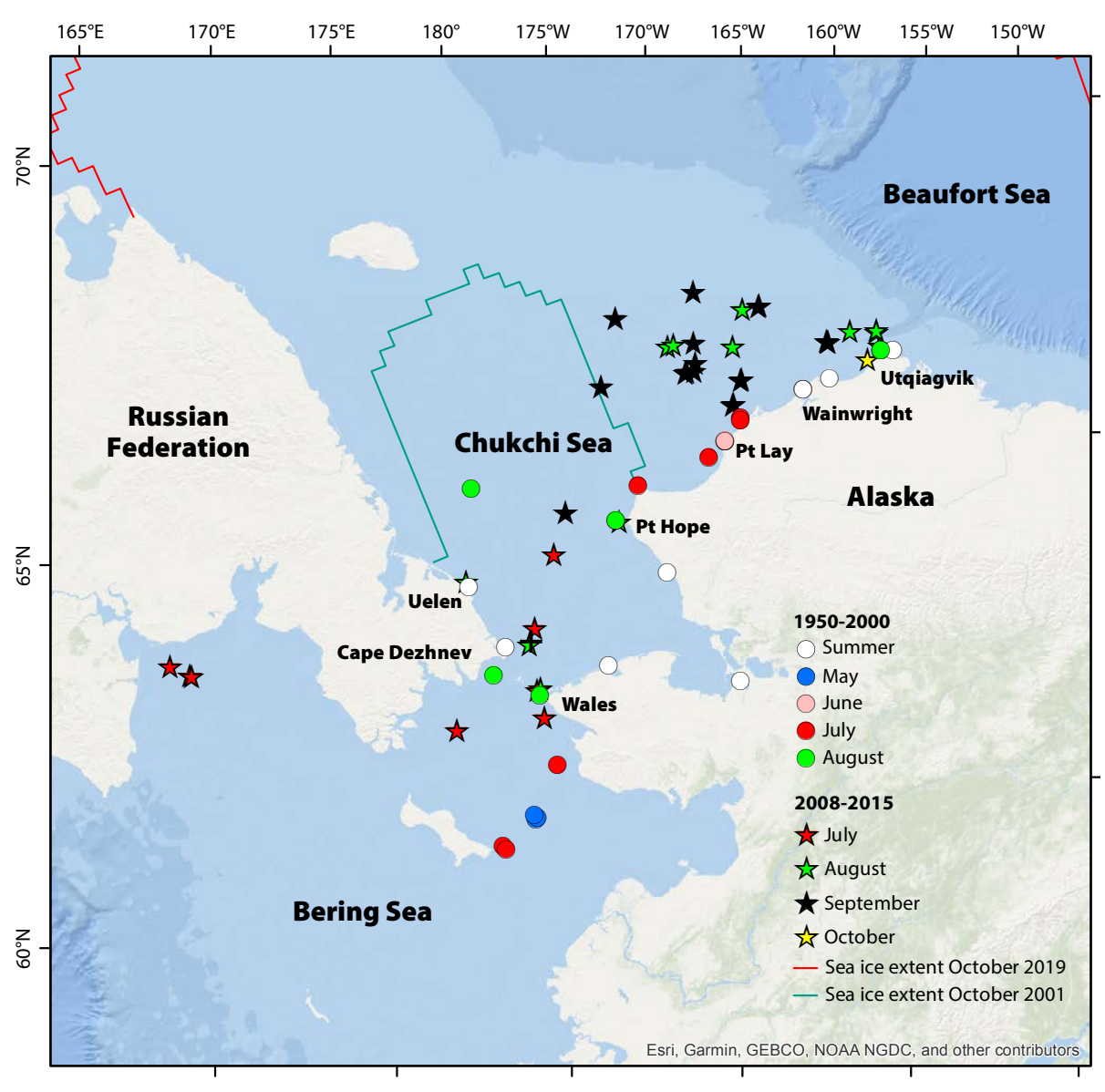

FIGURE 4. Killer whale sightings in the Pacific Arctic by month from 1950 to 2000 (circles) and 2008 to 2019 (stars). Sea ice extent is shown for October 2001 (blue line) and 2020 (red line). Adapted from Stafford (2019) 
competition for prey, novel predators, and exposure to novel pathogens will be critical (e.g., Post et al., 2013; Kortsch et al., 2015; VanWormer et al., 2019). The evidence we summarize here indicates large-scale shuffling of subarctic and Arctic marine animal communities as high-latitude marine ecosystems undergo rapid reorganization. 厄

\section{REFERENCES}

Ahonen, H., K.M. Stafford, C. Lydersen, C.L. Berchok, S.E. Moore, and K.M. Kovacs. 2021. Interannual variability in acoustic detection of blue and fin whale calls in the Northeast Atlantic High Arctic between 2008 and 2018. Endangered Species Research 45:209-224, https://doi.org/10.3354/ esr01132.

Alabia, I.D., J.G. Molinos, S.-I. Saitoh, T. Hirawake, T. Hirata, and F.J. Mueter. 2018. Distribution shifts of marine taxa in the Pacific Arctic under contemporary climate changes. Diversity and Distributions 24(11):1,583-1,597, https://doi.org/ 10.1111/ddi.12788.

Amélineau, F., J. Fort, P.D. Mathewson, D.C. Speirs, N. Courbin, S. Perret, W.P. Porter, R.J. Wilson, and D. Grémillet. 2018. Energyscapes and prey fields shape a North Atlantic seabird wintering hotspot under climate change. Royal Society Open Science 5(1):171883, https://doi.org/10.1098/ rsos.171883.

Bailey, K.M., T.J. Quinn, P. Bentzen, and W.S. Grant. 1999. Population structure and dynamics of walleye pollock, Theragra chalcogramma. Advances in Marine Biology 37:179-255, https://doi.org/10.1016/ S0065-2881(08)60429-0.

Berge, J., K. Heggland, O.J. Lønne, F. Cottier, H. Hop, G.W. Gabrielsen, L. Nottestad, and O.A. Misund. 2015. First records of Atlantic mackerel (Scomber scombrus) from the Svalbard Archipelago, Norway, with possible explanations for the extension of its distribution. Arctic 68(1):54-61, https://doi.org/ 10.14430/arctic4455.

Brower, A.A, J.T. Clarke, and M.C. Ferguson. 2018. Increased sightings of subarctic cetaceans in the eastern Chukchi Sea, 2008-2016: Population recovery, response to climate change, or increased survey effort? Polar Biology 41:1,033-1,039, https://doi.org/10.1007/s00300-018-2257-x.

Buchholz, F., T. Werner, and C. Buchholz. 2012. First observation of krill spawning in the high Arctic Kongsfjorden, West Spitsbergen. Polar Biology 35:1,273-1,279, https://doi.org/10.1007/ s00300-012-1186-3.

Clarke, J.T., K.M. Stafford, S.E. Moore, B. Rone, L. Aerts, and J. Crance. 2013. Subarctic cetaceans in the southern Chukchi Sea: Evidence of recovery or response to a changing ecosystem. Oceanography 26:136-149, https://doi.org/10.5670/ oceanog.2013.81.

Clarke, J.T., A.A. Brower, M.C. Ferguson, A.L. Willoughby, and A.D. Rotrock. 2020. Distribution and Relative Abundance of Marine Mammals in the Eastern Chukchi Sea, Eastern and Western Beaufort Sea, and Amundsen Gulf, 2019. Annual Report, OCS Study BOEM 2020-027, $628 \mathrm{pp}$.

Craig, P., and L. Haldorson. 1986. Pacific salmon in the North American Arctic. Arctic 39:2-7, https://doi.org/10.14430/arctic2037.
Daase, M., J. Berge, J.E. Søreide, and S. Falk-Petersen. 2021. Ecology of Arctic pelagic communities. Pp. 219-259 in Arctic Ecology. D.N. Thomas, ed., Wiley, https://doi.org/10.1002/ 9781118846582.ch9.

Day, R.H., A.E. Gall, T.C. Morgan, J.R. Rose, J.H. Plissner, P.M. Sanzenbacher, J.D. Fenneman, K.J. Kuletz, and B.H Watts. 2013. Seabirds new to the eastern Chukchi and Beaufort Seas, Alaska: Response to a changing climate? Western Birds 44(3):174-182

de Bruyn, P.J.N., C.A. Tosh, and A. Terauds. 2013. Killer whale ecotypes: Is there a global model? Biological Reviews 88:62-80, https://doi.org/ 10.1111/j.1469-185X.2012.00239.X.

De Robertis, A., K. Taylor, C.D. Wilson, and E.V. Farley 2017. Abundance and distribution of Arctic cod (Boreogadus saida) and other pelagic fishes over the U.S. Continental Shelf of the Northern Bering and Chukchi Seas. Deep Sea Research Part // 135:51-65, https://doi.org/10.1016/j.dsr2. 2016.03.002.

Descamps, S., and H. Strøm. 2021. As the Arctic becomes boreal: Ongoing shifts in a high-Arctic seabird community. Ecology 102(11):e03485, https://doi.org/10.1002/ecy.3485.

Divoky, G.J., E. Brown, and K.H. Elliott. 2021. Reduced seasonal sea ice and increased sea surface temperature change prey and foraging behaviour in an ice-obligate Arctic seabird, Mandt's Black Guillemot (Cepphus grylle mandtii). Polar Biology 44(4):701-715, https://doi.org/10.1007/ s00300-021-02826-3.

Drew, G.S., and J.F. Piatt. 2015. North Pacific Pelagic Seabird Database (NPPSD): U.S. Geological Survey data release (ver. 3.0, February 2020), https://doi.org/10.3133/ofr20151123.

Duffy-Anderson, J.T., P. Stabeno, A.G. Andrews, K. Cieciel, A. Deary, E. Farley, C. Fugate, C. Harpold, R. Heintz, D. Kimmel, and others. 2019 Responses of the northern Bering Sea and southeastern Bering Sea pelagic ecosystems following record-breaking low winter sea ice. Geophysical Research Letters 46(1):9,833-9,842, https://doi.org/ 10.1029/2019GL083396.

Dunmall, K.M., J.D. Reist, E.C. Carmack, J.A. Babluk, M.P. Heide-Jørgensen, and M.F. Docker. 2013. Pacific salmon in the Arctic: Harbingers of change. Pp. 141-163 in Responses of Arctic Marine Ecosystems to Climate Change. F.J. Mueter, D.M.S. Dickson, H.P. Huntington, J.R. Irvine, E.A. Logerwell, S.A. MacLean, L.T. Quakenbush, and C. Rosa, eds, Alaska Sea Grant, University of Alaska Fairbanks, https://doi.org/10.4027/ ramecc.2013.07.

Dunmall, K.M., N.J. Mochnacz, C.E. Zimmerman, C. Lean, and J.D. Reist. 2016. Using thermal limits to assess establishment of fish dispersing to high-latitude and high-elevation watersheds. Canadian Journal of Fisheries and Aquatic Sciences 73:1,750-1,758, https://doi.org/10.1139/ cjfas-2016-0051.

Dunmall, K.M., D.G. McNicholl, and J.D. Reist. 2018 Community-based monitoring demonstrates increasing occurrences and abundances of Pacific salmon in the Canadian Arctic from 2000 to 2017. Pp. 87-90 in North Pacific Anadromous Fish Commission Technical Report 11.

Eisner, L., N. Hillgruber, E. Martinson, and J. Maselko. 2013. Pelagic fish and zooplankton species assem blages in relation to water mass characteristics in the northern Bering and southeast Chukchi Seas. Polar Biology 36(1):87-113, https://doi.org/10.1007/ s00300-012-1241-0.

Eisner, L.B., Y.I. Zuenko, E.O. Basyuk, L.L. Britt, J.T. Duffy-Anderson, S. Kotwicki, C. Ladd, and W. Cheng. 2020. Environmental impacts on walleye pollock (Gadus chalcogrammus) distribution across the Bering Sea shelf. Deep-Sea Research Part // 181-182:104881, https://doi.org/10.1016/ j.dsr2.2020.104881.

Eriksen, E., E. Bagøien, E. Strand, R. Primicerio, T. Prokhorova, A. Trofimov, and I. Prokopchuk. 2020. The record-warm Barents Sea and 0-Group fish response to abnormal conditions. Frontiers in Marine Science 7:338, https://doi.org/10.3389/ fmars.2020.00338.

Farley, E.V. Jr., J.M. Murphy, K. Cieciel, E.M. Yasumiishi, K. Dunmall, T. Sformo, and P. Rand. 2020. Response of Pink salmon to climate warming in the northern Bering Sea. Deep Sea Research Part // 177:104839, https://doi.org/10.1016/j.dsr2. 2020.104830.

Ferguson, M.C., J. Waite, C. Curtice, J.T. Clarke, and J. Harrison. 2015. Biologically important areas for cetaceans within US waters: Aleutian Islands and Bering Sea region. Aquatic Mammals 41(1):79-93, https://doi.org/10.1578/AM.41.1.2015.79.

Ferguson, S.H., J.W. Higdon, and E.G. Chmelnitsky. 2010. The rise of killer whales as a major Arctic predator. Pp. 117-136 in A Little Less Arctic: Top Predators in the World's Largest Northern Inland Sea, Hudson Bay. S.H. Ferguson, L.L. Loseto, and M.L. Mallory, eds, Springer, https://doi.org/ 10.1007/978-90-481-9121-5_6.

Fossheim, M., R. Primicerio, E. Johannesen, R.B. Ingvaldsen, M.M. Aschan, and A.V. Dolgov. 2015. Recent warming leads to a rapid borealization of fish communities in the Arctic. Nature Climate Change 5:673-678, https://doi.org/10.1038/ nclimate 2647.

Frainer, A., R. Primicerio, S. Kortsch, M. Aune, A.V. Dolgov, M. Fossheim, and M.M. Aschan. 2017 Climate-driven changes in functional biogeography of Arctic marine fish communities. Proceedings of the National Academy of Sciences of the United States of America 114(46):12,202-12,207, https://doi.org/10.1073/pnas.1706080114.

Frederiksen, M., T. Anker-Nilssen, G. Beaugrand, and S. Wanless. 2013. Climate, copepods and seabirds in the boreal northeast Atlantic-Current state and future outlook. Global Change Biology 19:364-372, https://doi.org/10.1111/gcb.12072.

Gall, A.E., R.H. Day, and T.J. Weingartner. 2013. Structure and variability of the marine-bird community in the northeastern Chukchi Sea. Continental Shelf Research 67:96-115, https://doi.org/10.1016/ j.csr.2012.11.004.

Gall, A.E., T.C. Morgan, R.H. Day, and K.J. Kuletz. 2017. Ecological shift from piscivorous to planktivorous seabirds in the Chukchi Sea, 1975-2012. Polar Biology 40(1):61-78, https://doi.org/10.1007/ s00300-016-1924-z.

George, J.C., G. Sheffield, D.J. Reed, B. Tudor, R. Stimmelmayr, B.T. Person, T. Sformo, and R. Suydam. 2017. Frequency of injuries from line entanglements, killer whales, and ship strikes on Bering-Chukchi-Beaufort Seas bowhead whales. Arctic 70(1):37-46, https://doi.org/10.14430/ arctic4631.

Goddard, P., R. Lauth, and C. Armistead. 2014. Results of the 2012 Chukchi Sea Bottom Trawl Survey of Bottomfishes, Crabs, and Other Demersal Macrofauna. NOAA Technical Memorandum, NMFS-AFSC-278, $110 \mathrm{pp}$.

Grebmeier, J.M., and W. Maslowski, eds. 2014 The Pacific Arctic Region. Springer, Netherlands, https://doi.org/10.1007/978-94-017-8863-2.

Grüss, A., J.T. Thorson, C.C. Stawitz, J.C.P. Reum, S.K. Rohan, and C.L. Barnes. 2021. Synthesis of interannual variability in spatial demographic processes supports the strong influence of coldpool extent on eastern Bering Sea walleye pollock (Gadus chalcogrammus). Progress in Oceanography 194:102569, https://doi.org/10.1016/ j.pocean.2021.102569. 
Hamilton, C.D., C. Lydersen, J. Aars, M. Biuw, A.N. Boltunov, E.W. Born, R. Dietz, L.P. Foklow, D.M. Glazov, T. Haug, and others. 2021. Marine mammal hotspots in the Greenland and Barents Seas. Marine Ecology Progress Series 659:3-28, https://doi.org/10.3354/meps13584.

Higdon, J.W., and S.H. Ferguson. 2009. Loss of Arctic sea ice causing punctuated change in sightings of killer whales (Orcinus orca) over the past century. Ecological Applications 19:1,365-1,375, https://doi.org/10.1890/07-1941.1.

Hunt, G.L. Jr., V. Bakken, and F. Mehlum. 1996. Marine birds in the marginal ice zone of the Barents Sea in late winter and spring. Arctic 49(1):53-61, https://doi.org/10.14430/arctic1183.

Hunt, G.L. Jr., A.L. Blanchard, P. Boveng,

P. Dalpadado, K.F. Drinkwater, L. Eisner, R.R. Hopcroft, K.M. Kovacs, B.L. Norcross, P. Renaud, and others. 2013. The Barents and Chukchi Seas: Comparison of two Arctic shelf ecosystems. Journal of Marine Systems 109-110:43-68, https://doi.org/10.1016/j.jmarsys.2012.08.003.

Hunt, G.L. Jr., M. Renner, K.J. Kuletz, S. Salo, L. Eisner, P.H. Ressler, C. Ladd, and J.A. Santora. 2018. Timing of sea-ice-retreat affects the distribution of seabirds and their prey in the southeastern Bering Sea. Marine Ecology Progress Series 593:209-230, https://doi.org/10.3354/meps12383.

Huntington, H.P., L.T. Quakenbush, and M. Nelson. 2016. Effects of changing sea ice on marine mammals and subsistence hunters in northern Alaska from traditional knowledge interviews. Biology Letters 12(8):20160198, https://doi.org/10.1098/ rsbl.2016.0198.

Huntington, H.P., S.L. Danielson, F.K. Wiese, M. Baker, P. Boveng, J.J. Citta, A. De Robertis, D.M.S. Dickson, E. Farley, J.C. George, and others. 2020. Evidence suggests potential transformation of the Pacific Arctic ecosystem is underway. Nature Climate Change 10:342-348, https://doi.org/10.1038/ s41558-020-0695-2.

Huntington, H.P., J. Raymond-Yakoubian, G. Noongwook, N. Naylor, C. Harris, Q. Harcharek and B. Adams. 2021. "We Never Get Stuck": A collaborative analysis of change and coastal community subsistence practices in the northern Bering and Chukchi Seas, Alaska. Arctic 74:113-126, https://doi.org/10.14430/arctic72446.

Johannesen, E., Å.S. Høines, A.V. Dolgov, and M. Fossheim. 2012. Demersal fish assemblages and spatial diversity patterns in the ArcticAtlantic transition zone in the Barents Sea. PLoS ONE 7(4): e34924, https://doi.org/10.1371/journal. pone.0034924.

Kortsch, S., R. Primicerio, M. Fossheim, V. Dolgov, and M. Aschan. 2015. Climate change alters the structure of Arctic marine food webs due to poleward shifts of boreal generalists. Proceedings of the Royal Society B 282(1814):20151546, https://doi.org/ 10.1098/rspb.2015.1546.

Kotwicki, S., T.W. Buckley, T. Honkalehto, and G. Walters. 2005. Variation in the distribution of walleye pollock (Theragra chalcogramma) with temperature and implications for seasonal migration. Fishery Bulletin 103(4):574-587.

Kuletz, K.J., M. Renner, E.A. Labunski, and G.L. Hunt Jr. 2014. Changes in the distribution and abundance of albatrosses in the eastern Bering Sea: 19752010. Deep Sea Research Part I/ 109:282-292, https://doi.org/10.1016/j.dsr2.2014.05.006.

Kuletz, K.J., M.C. Ferguson, B. Hurley, A.E. Gall, E.A. Labunski, and T.C. Morgan. 2015. Seasonal spatial patterns in seabird and marine mammal distribution in the eastern Chukchi and western Beaufort Seas: Identifying biologically important pelagic areas. Progress in Oceanography 136:175-200, https://doi.org/ 10.1016/j.pocean.2015.05.012.
Kuletz, K., D. Cushing, and E. Labunski. 2020. Distributional shifts among seabird communities of the northern Bering and Chukchi seas in response to ocean warming during 20172019. Deep Sea Research Part // 181-182:104913, https://doi.org/10.1016/j.dsr2.2020.104913.

Laidre, K.L., I. Stirling, L.F. Lowry, Ø. Wiig, M.P. HeideJørgensen, and S.H. Ferguson. 2008. Quantifying the sensitivity of Arctic marine mammals to climate-induced habitat change. Ecological Applications 18:S97-S125, https://doi.org/ 10.1890/06-0546.1.

Laurel, B.J., M. Spencer, P. Iseri, and L.A. Copeman. 2016. Temperature-dependent growth and behavior of juvenile Arctic cod (Boreogadus saida) and co-occurring North Pacific gadids. Polar Biology 39:1,127-1,135, https://doi.org/10.1007/ s00300-015-1761-5.

Laurel, B.J., L.A. Copeman, M. Spencer, and P. Iseri. 2018. Comparative effects of temperature on rates of development and survival of eggs and yolk-sac larvae of Arctic cod (Boreogadus saida) and walleye pollock (Gadus chalcogrammus). ICES Journal of Marine Science 75:2,403-2,412, https://doi.org/ 10.1093/icesjms/fsy042.

Lefort, K.J., C.J. Garroway, and S.H. Ferguson. 2020. Killer whale abundance and predicted narwhal consumption in the Canadian Arctic. Global Change Biology 26:4,276-4,283, https://doi.org/10.1111/ gcb.15152.

Levine, R.M., A. De Robertis, D. Grünbaum, R. Woodgate, C.W. Mordy, F. Mueter, E. Cokelet, N. Lawrence-Slavas, and H. Tabisola. 2021. Autonomous vehicle surveys indicate that flow reversals retain juvenile fishes in a highly advective high-latitude ecosystem. Limnology and Oceanography 66:1,139-1,154, https://doi.org/ 10.1002/Ino.11671.

Mallory, M.L., A.J. Gaston, H.G. Gilchrist, G.J. Robertson, and B.M. Braune. 2010. Effects of climate change, altered sea-ice distribution and seasonal phenology on marine birds. Pp. 179-195 in A Little Less Arctic: Top Predators in the World's Largest Northern Inland Sea, Hudson Bay. S.H. Ferguson, ed., Springer, https://doi.org/10.1007/ 978-90-481-9121-5_9.

Matthews, C.J.D., S.P. Luque, S.D. Petersen, R.D. Andrews, and S.H. Ferguson. 2011. Satellite tracking of a killer whale (Orcinus orca) in the Eastern Canadian Arctic documents ice avoidance and rapid, long-distance movement into the North Atlantic. Polar Biology 34:1,091-1,096, https://doi.org/10.1007/s00300-010-0958-x.

Matthews, C.J.D., S.A. Raverty, D.P. Noren, L. Arragutainaq, and S.H. Ferguson. 2019. Ice entrapment mortality may slow expanding presence of Arctic killer whales. Polar Biology 42:639-644, https://doi.org/10.1007/ s00300-018-02447-3.

Matthews, C.J.D., G.A. Breed, B. LeBlanc, and S.H. Ferguson. 2020. Killer whale presence drives bowhead whale selection for sea ice in Arctic seascapes of fear. Proceedings of the National Academy of Sciences of the United States of America 117(12):6,590-6,598, https://doi.org/ 10.1073/pnas.1911761117.

Mecklenburg, C.W., D.L. Stein, B.A. Sheiko, N.V. Chernova, T.A. Mecklenburg, and B.A. Holladay. 2007. Russian-American Long-Term Census of the Arctic: Benthic fishes trawled in the Chukchi Sea and Bering Strait, August 2004. Northwestern Naturalist 88:168-187, https://doi.org/ 10.1898/1051-1733(2007)88[168:RLCOTA]2.0.CO;2.

Moore, S.E., E. Logerwell, L. Eisner, E.V. Farley Jr., L.A. Harwood, K. Kuletz, J. Lovvorn, J.R. Murphy, and L.T. Quakenbush. 2014. Marine fishes, birds and mammals as sentinels of ecosystem variability and reorganization in the Pacific Arctic region. Pp. 337-392 in The Pacific Arctic Region:
Ecosystem Status and Trends in a Rapidly Changing Environment. J.M. Grebmeier and W. Maslowski, eds, Springer, https://doi.org/ 10.1007/978-94-017-8863-2_11.

Moore S.E., and R.R. Reeves. 2018. Tracking arctic marine mammal resilience in an era of rapid ecosystem alteration. PLoS Biology 16:e2006708, https://doi.org/10.1371/journal.pbio.2006708.

Moore, S.E., and K.J. Kuletz. 2019. Marine birds and mammals as ecosystem sentinels in and near Distributed Biological Observatory regions: An abbreviated review of published accounts and recommendations for integration to ocean observatories. Deep-Sea Research Part // 162:211-217, https://doi.org/10.1016/j.dsr2.2018.09.004.

Moore, S.E., T. Haug, G.A. Vikingsson, and G.B. Stenson. 2019. Baleen whale ecology in Arctic and subarctic seas in an era of rapid habitat alteration. Progress in Oceanography 176:102118, https://doi.org/10.1016/j.pocean.2019.05.010.

Moss, J.H., J.M. Murphy, E.V. Farley, L.B. Eisner, A.G. Andrews. 2009. Juvenile pink and chum salmon distribution, diet, and growth in the northern Bering and Chukchi Seas. North Pacific Anadromous Fish Commission Bulletin 5:191-196.

Mueter, F.J., B. Planque, G.L. Hunt, I.D. Alabia, T. Hirawake, L. Eisner, P. Dalpadado, M. Chierici, K.F. Drinkwater, N. Harada, and others. 2021a. Possible future scenarios in the gateways to the Arctic for subarctic and Arctic marine systems: Prey resources, food webs, fish, and fisheries. ICES Journal of Marine Science 78:3,017-3,045, https://doi.org/10.1093/icesjms/fsab122.

Mueter, F.J., K. Iken, L.W. Cooper, J.M. Grebmeier, K.J. Kuletz, R.R. Hopcroft, S.L. Danielson, R.E. Collins, and D.A. Cushing, 2021b. Changes in diversity and species composition across multiple assemblages in the northeast Chukchi Sea during two contrasting years are consistent with borealization. Oceanography 34(2):38-51, https://doi.org/ 10.5670/oceanog.2021.213.

Nielsen, J.L., G.T. Ruggerone, and C.E. Zimmerman. 2013. Adaptive strategies and life history characteristics in a warming climate: Salmon in the Arctic? Environmental Biology of Fishes 96:1,187-1,226 https://doi.org/10.1007/s10641-012-0082-6.

Nieukirk, S.L., D.K. Mellinger, R.P. Dziak, H. Matsumoto, and H. Klinck. 2020. Multi-year occurrence of sei whale calls in North Atlantic polar waters. The Journal of the Acoustical Society of America 147:1,842-1,850, https://doi.org/10.1121/ 10.0000931.

Orlov, A.M., A.N. Benzik, E.V. Vedischeva, S.V. Gafitsky, K.M. Gorbatenko, S.V. Goryanina, V.L. Zubarevich, Q.V. Kodryan, M.A. Nosov, S.Yu. Orlova, and others. 2020. Fisheries research in the Chukchi Sea at the RV Professor Levanidov in August 2019: Some preliminary results. Trudy VNIRO 179:206-220, https://doi.org/10.36038/ 2307-3497-2020-179-206-225.

Oziel, L., G. Neukermans, M. Ardyna, C. Lancelot, J.L. Tison, P. Wassmann, J. Sirven, D. Ruiz-Pino, and J.-C. Gascard. 2017. Role for Atlantic inflows and sea ice loss on shifting phytoplankton blooms in the Barents Sea. Journal of Geophysical Research: Oceans 122:5,121-5,139, https://doi.org/10.1002/ 2016JC012582.

Pecuchet, L., M.-A. Blanchet, A. Frainer, B. Husson, L.L. Jørgensen, S. Kortsch, and R. Primicerio. 2020. Novel feeding interactions amplify the impact of species redistribution on an Arctic food web. Global Change Biology 26:4,894-4,906, https://doi.org/10.1111/gcb.15196.

Pinsky, M.L., B. Worm, M.J. Fogarty, J.L. Sarmiento, and S.A. Levin. 2013. Marine taxa track local climate velocities. Science 341(6151):1,239-1,242, https://doi.org/10.1126/science.1239352. 
Polyakov, I.V., M.B. Alkire, B.A. Bluhm, K.A. Brown, E.C. Carmack, M. Chierici, S.L. Danielson, I. Ellingsen, E.A. Ershova, K. Gårdfeldt, and others, 2020. Borealization of the Arctic Ocean in response to anomalous advection from subArctic seas. Frontiers in Marine Science 7:491, https://doi.org/10.3389/fmars.2020.00491.

Post, E., U.S. Bhatt, C.M. Bitz, J.F. Brodie, T.L. Fulton, M. Hebblewhite, J. Kerby, S.J. Kutz, J. Stirling, and D.A. Walker. 2013. Ecological consequences of sea-ice decline. Science 341(6145): 519-524, https://doi.org/10.1126/science.1235225.

Radchenko, V.I., R.J. Beamish, W.R. Heard, O.S. Temnykh. 2018. Ocean ecology of pink salmon. Pp. 15-160 in The Ocean Ecology of Pacific Salmon and Trout. R.J. Beamish, ed., American Fisheries Society, Bethesda, Maryland, https://doi.org/10.47886/9781934874455.ch2.

Rand, K.M., and E.A. Logerwell. 2011. The first demersal trawl survey of benthic fish and invertebrates in the Beaufort Sea since the late 1970s. Polar Biology 34(4):475-488, https://doi.org/10.1007/ s00300-010-0900-2.

Reinhart, N.R., S.H. Ferguson, W.R. Koski, J.W. Higdon, B. Leblanc, O. Tervo, and P.D. Jepson. 2013. Occurrence of killer whale Orcinus orca rake marks on Eastern Canada-West Greenland bowhead whales Balaena mysticetus. Polar Biology 36:1,133-1,146, https://doi.org/10.1007/ s00300-013-1335-3.

Renner, M., J.K. Parrish, J.F. Piatt, K.J. Kuletz, A.E. Edwards, and G.L. Hunt Jr. 2013. Modeled distribution and abundance of a pelagic seabird reveal trends in relation to fisheries. Marine Ecology Progress Series 484:259-277, https://doi.org/10.3354/meps10347.

Romano, M., H.M. Renner, K.J. Kuletz, J.K. Parrish, T. Jones, H.K. Burgess, D.A. Cushing, and D. Causey. 2020. Die-offs and reproductive failure of murres in the Bering and Chukchi Seas in 2018. Deep Sea Research Part // 181-182, https://doi.org/ 10.1016/j.dsr2.2020.104877.

Ruggerone, G.T., and J.R. Irvine. 2018. Numbers and biomass of natural- and hatchery-origin pink salmon, chum salmon, and sockeye salmon in the North Pacific Ocean, 1925-2015. Marine and Coastal Fisheries 10:152-168, https://doi.org/ 10.1002/mcf2.10023.

Ryan, W.B.F., S.M. Carbotte, J. Coplan, S. O'Hara, A. Melkonian, R. Arko, R.A. Weissel, V. Ferrini, A. Goodwillie, F. Nitsche, and others. 2009. Global Multi-Resolution Topography (GMRT) synthesis data set. Geochemistry, Geophysics, Geosystems 10, Q03014, https://doi.org/10.1029/2008GC002332.

Sigler, M., M. Renner, S. Danielson, L. Eisner, R. Lauth, K. Kuletz, E. Logerwell, and G. Hunt. 2011. Fluxes, fins, and feathers: Relationships among the Bering, Chukchi, and Beaufort Seas in a time of climate change. Oceanography 24:250-265, https://doi.org/10.5670/oceanog.2011.77.

Sorte, C.J.B., S.L. Williams, and J.T. Carlton. 2010. Marine range shifts and species introductions: Comparative spread rates and community impacts. Global Ecology and Biogeography 19:303-316, https://doi.org/10.1111/j.1466-8238.2009.00519.x.

Stabeno, P.J., and S.W. Bell. 2019. Extreme conditions in the Bering Sea (2017-2018): Recordbreaking low sea-ice extent. Geophysical Research Letters 46:8,952-8,959, https://doi.org/ 10.1029/2019GL083816.

Stabeno, P.J., N.A. Bond, N.B. Kachel, S.A. Salo, and J.D. Schumacher. 2001. On the temporal variability of the physical environment over the south-eastern Bering Sea. Fisheries Oceanography 10:81-98, https://doi.org/10.1046/j.1365-2419.2001.00157.x.
Stafford, K.M. 2019. Increasing detections of killer whales (Orcinus orca) in the Pacific Arctic. Marine Mammal Science 35:696-706, https://doi.org/ 10.1111/mms.12551.

Stafford, K.M., S.E. Moore, P.J. Stabeno, D.V. Holliday, J.M. Napp, and D.K. Mellinger. 2010. Biophysical ocean observation in the southeastern Bering Sea. Geophysical Research Letters 37:L02606, https://doi.org/10.1029/2009GL040724.

Stafford, K.M., J.J. Citta, S. Okkonen, and J. Zhang. 2021. Bowhead and beluga whale acoustic detections in the western Beaufort Sea 2008-2018. PLoS ONE 16(6):e0253929, https://doi.org/10.1371/ journal.pone.0253929.

Stevenson, D.E., and R.R. Lauth. 2019. Bottom trawl surveys in the northern Bering Sea indicate recent shifts in the distribution of marine species. Polar Biology 42:407-421, https://doi.org/10.1007/ s00300-018-2431-1.

Storrie, L., C. Lydersen, M. Andersen, R.B. Wynn, and K.M. Kovacs. 2018. Determining the species assemblage and habitat use of cetaceans in the Svalbard Archipelago, based on observations from 2002 to 2014. Polar Research 37, https://doi.org/10.1080/175 18369.2018.1463065.

Sydeman, W., S.A. Thompson, J. Santora, M. Henry, K.H. Morgan, and S. Batten. 2010. Macroecology of plankton-seabird associations in the North Pacific Ocean. Journal of Plankton Research 32:1,697-1,713, https://doi.org/10.1093/ plankt/fbq119.

Sydeman, W.J., S.A. Thompson, J.F. Piatt, S.G. Zador, and M.W. Dorn. 2021. Integrating seabird dietary and groundfish stock assessment data: Can puffins predict pollock spawning stock biomass in the North Pacific? Fish and Fisheries 23:213-226, https://doi.org/10.1111/faf.12611.

Tamarin-Brodsky, T., and Y. Kaspi. 2017. Enhanced poleward propagation of storms under climate change. Nature Geoscience 10:908-914, https://doi.org/10.1038/s41561-017-0001-8.

Thoman, R.L., J. Richter-Menge, and M.L. Druckenmiller. 2020. Arctic Report Card 2020: Executive Summary, https://doi.org/10.25923/ mn5p-t549.

VanWormer, E., J.A.K. Mazet, A. Hall, V.A. Gill, P.L. Boveng, J.M. London, T. Gelatt, B.S. Fadely, M.E. Lander, J. Sterling, and others. 2020. Viral emergence in marine mammals in the North Pacific may be linked to Arctic sea ice reduction. Scientific Reports 9:15569, https://doi.org/10.1038/ s41598-019-51699-4.

Westdal, K.H., J.W. Higdon, and S.H. Ferguson. 2016. Review of killer whale (Orcinus orca) ice entrapments and ice-related mortality events in the Northern Hemisphere. Polar Biology 40:1,467-1,473, https://doi.org/10.1007/ s00300-016-2019-6.

Will, A., A. Takahashi, J.-B. Thiebot, A. Martinez, E. Kitaiskaia, L. Britt, D. Nichol, J. Murphy, A. Dimond, S. Tsukamoto, and others. 2020. The breeding seabird community reveals that recent sea ice loss in the Pacific Arctic does not benefit piscivores and is detrimental to planktivores. Deep-Sea Research Part // 181-182:104902, https://doi.org/10.1016/j.dsr2.2020.104902.

Willoughby, A.L., M.C. Ferguson, R. Stimmelmayr, J.T. Clarke, and A.A. Brower. 2020. Bowhead whale (Balaena mysticetus) and killer whale (Orcinus orca) co-occurrence in the U.S. Pacific Arctic, 2009-2018: Evidence from bowhead whale carcasses. Polar Biology 43:1,669-1,697, https://doi.org/10.1007/s00300-020-02734-y.

Woodgate, R.A., and C. Peralta-Ferriz. 2021. Warming and freshening of the Pacific inflow to the Arctic from 1990-2019 implying dramatic shoaling in Pacific winter water ventilation of the Arctic water column. Geophysical Research Letters 48(9):e2021GL092528, https://doi.org/ 10.1029/2021GL092528.

Wyllie-Echeverria, T. 1995. Sea-ice conditions and the distribution of walleye pollock (Theragra chalcogramma) on the Bering and Chukchi Sea shelf. Pp. 131-136 in Climate Change \& Northern Fish Populations. R.J. Beamish, ed., Canadian Special Publication of Fisheries and Aquatic Sciences, vol. 121, National Research Council of Canada, Ottawa.

\section{ACKNOWLEDGMENTS}

Support for this work was provided to KMS by NPRB grant A94-00 and ONR grants N000141712274 and N000142012413. D. Cushing kindly produced Figure 3 . The scientific results and conclusions, as well as any views or opinions expressed herein, are those of the author(s) and do not necessarily reflect those of NOAA or the Department of Commerce or the US Fish and Wildlife Service. Reference to trade names does not imply endorsement by the National Marine Fisheries Service or NOAA.

\section{AUTHORS}

Kathleen M. Stafford (kate.stafford@oregonstate.edu) was Senior Principal Oceanographer, Applied Physics Laboratory, University of Washington, Seattle, WA, USA, and is now Associate Professor, Marine Mammal Institute, Oregon State University, Newport, OR, USA. Edward V. Farley is Program Manager, Alaska Fisheries Science Center, National Oceanographic and Atmospheric Administration (NOAA), Juneau, AK, USA. Megan Ferguson is Research Fisheries Biologist, Alaska Fisheries Science Center, NOAA, Seattle, WA, USA. Kathy J. Kuletz is Supervisory Wildlife Biologist, US Fish and Wildlife Service, Anchorage, AK, USA. Robert Levine is a graduate student in biological oceanography, School of Oceanography, University of Washington, Seattle, WA, USA.

\section{ARTICLE CITATION}

Stafford, K.M., E.V. Farley, M. Ferguson, K.J. Kuletz, and R. Levine. 2022. Northward range expansion of subarctic upper trophic level animals into the Pacific Arctic region. Oceanography, https://doi.org/10.5670/ oceanog.2022.101.

\section{COPYRIGHT \& USAGE}

This is an open access article made available under the terms of the Creative Commons Attribution 4.0 International License (https://creativecommons.org/ licenses/by/4.0/), which permits use, sharing, adaptation, distribution, and reproduction in any medium or format as long as users cite the materials appropriately, provide a link to the Creative Commons license, and indicate the changes that were made to the original content. 